\title{
The Vacant Chair on the Farm: Soldier Husbands, Farm Wives, and the Iowa Home Front, 1861-1865
}

\author{
J. L. ANDERSON
}

IN LATE MAY 1865, Ann Larimer wrote to her absent husband, Union soldier John Larimer, about the state of their family farm in Adams County, Iowa. She reported that the two sheep she had purchased the previous fall had increased to four. It was important news; keeping twin lambs alive can be demanding work. The prospect of raising more lambs meant more fleeces, which promised more income. During the war years there was high demand for wool for military uniforms, and it commanded a premium price. Any doubt about Larimer's satisfaction with her accomplishment vanished with the next line: "Don't you think I would make quite a farmer providing I had a husband to do the work?" Larimer's comment simultaneously reveals pride in accomplishment and recognition of the limits imposed by wartime separation of spouses. ${ }^{1}$

Ann Larimer and thousands of other women lived with a "vacant chair" on their farms that transformed their lives for the

1. Ann Larimer to John W. Larimer, 5/28/1865, Ann Larimer Collection, Iowa Women's Archives, University of Iowa Libraries, Iowa City.

I am grateful to the State Historical Society of Iowa (SHSI) for a research grant as well as to Marvin Bergman and the anonymous reviewers for the Annals of Iowa for their critiques. Historians and archivists gave valuable assistance at different stages of this project. They include Ginette Aley, Sharon Avery (SHSI, Des Moines), Tom Colbert, Mary Bennett (SHSI, Iowa City), Kathy Hodson (Special Collections, University of Iowa Libraries), Alexandra Kindell, Kären Mason (Iowa Women's Archives), and John Zeller.

THE ANNALS OF IOWA 66 (Summer-Fall 2007). (C) The State Historical Society of Iowa, 2007. 
duration of the war. "The Vacant Chair" was the title of a popular song composed by George F. Root in 1862 that described the loss of a loved one killed in action. But the song's reference to the vacant chair was also a daily symbol of wartime separation and the unresolved issue of whether or not men would return to occupy their chairs in parlors or at family tables. Even more than a symbol, it was a reality that shaped the wartime experiences of Iowa farm men and women in significant ways.

Women had always been partners and, to varying degrees, decision makers in the farm enterprise. But confronted with the absence of husbands, they often made significant decisions about farm affairs on their own, sometimes in consultation by correspondence with husbands or other male kin. Some women performed new tasks in fields and farmyards, although relatively few women conducted the kinds of physical farm labor that their husbands had performed before the war. Farm women were busy with other farm work and childrearing and, in what appears to be a common occurrence, left the farms they operated in partnership with their husbands and moved in with the husband's or wife's parents. For many women, then, the war was a retreat from the farm to a more secure position within the homes of kin. Suffering and sacrifice were widespread on the home front, just as they were on the battlefront. In the absence of their husbands, women confronted many hardships and in many cases performed unfamiliar tasks, although they confronted those challenges with a high degree of cooperation or mutuality with husbands via correspondence. The provoking lines from Ann Larimer to her husband suggest that the war brought limited but important change for farm women whose husbands were in the military. ${ }^{2}$

2. Reid Mitchell, The Vacant Chair: The Northern Soldier Leaves Home (New York, 1993). Only a handful of historians have paid attention to Northern farm women during the Civil War, in spite of a recent flowering of Northern home front studies and a long-established subfield of the history of Southern women during wartime. Glenda Riley, Frontierswomen, The Iowa Experience (Ames, 1981), emphasized the hardships and painful adjustments endured by Iowa farm women. Nancy Grey Osterud, "Rural Women during the Civil War: New York's Nanticoke Valley, 1861-1865," New York History 71 (1990), 357-85, contended that while most women and men cooperated to maintain the family, the most successful women enlarged their scope of activities to include work that traditionally had been performed by men. More recently, Thomas E. Rodgers, 
Traditional interpretations of wartime agriculture and rural life in the North emphasize the role of mechanization and the labor of women, children, the elderly, and immigrants in meeting the surging domestic and foreign demand for commodities. In the only book-length study of agriculture during the war, now over 40 years old, Paul W. Gates concluded, based on reports from the farm press, that women played a critical role in work in the fields and farmyards across the North. ${ }^{3}$ Evidence from the farm press, however, needs to be supplemented by correspondence between spouses, the most intimate evidence we have, to discover actual conditions on the farm. Understanding the ways farm families coped with the problem of keeping farms intact while enduring the separation of military service requires a fresh look through the lens of the couples who endured the war.

The correspondence between soldiers and their wives is central to understanding the wartime experience on Iowa's farms. ${ }^{4}$ Of the extant collections of letters, those from men are

"Hoosier Women and the Civil War Home Front," Indiana Magazine of History 97 (2001), 105-28, concluded that the war was not a watershed for most Indiana women in terms of gendered work on the farm. Judith Ann Giesberg, "From Harvest Field to Battlefield: Rural Pennsylvania Women and the U.S. Civil War," Pennsylvania History 72 (2005), 158-91, concluded that when husbands of rural Pennsylvania women left for war, "women's work on the farm expanded to fill the void." For the most part, however, Northern home front studies have focused on urban women and those involved in public affairs or organizations. Recent home front studies that offer little on rural women include Paul A. Cimbala and Randall M. Miller, eds., Union Soldiers and the Northern Home Front (New York, 2002); Jeanie Attie, Patriotic Toil: Northern Women and the American Civil War (Ithaca, NY, 1998); Elizabeth D. Leonard, Yankee Women: Gender Battles in the Civil War (New York, 1994); J. Matthew Gallman, The North Fights the Civil War: The Home Front (Chicago, 1994); and Phillip Shaw Paludan, "A People's Contest": The North and the Civil War, 18611865 (New York, 1988).

3. Earle D. Ross, Iowa Agriculture (Iowa City, 1951), 54; Edwin J. Gilford, "The Agricultural Labor Shortage in the Northwest during the Civil War and How It Was Met, 1860-1865" (M.A. thesis, Miami University, 1956), 100; Paul W. Gates, Agriculture and the Civil War (New York, 1965), 242-43.

4. The major research effort for this project was to locate manuscript collections and published letters of married farm men and women. That task required reading many collections to determine if the letter writers actually discussed farm affairs and consulting the Roster and Record of Iowa Soldiers in the War of Rebellion to assess if the men listed their occupation as farmer. 
more common than those of their wives since it was easier for someone at home to keep letters than it was for soldiers to keep all of the letters they received. But even in collections with onesided correspondence from the husband and few or no letters from the wife it is still possible to understand at least some of the expectations and hopes that men had for their spouses and to learn what they reported that their wives did on the farm. What emerges from these exchanges is the extent to which managing the farm, at least during wartime, was characterized by a high degree of mutuality, or a shared sense of responsibility for the success of the farm. Mutuality did not necessarily mean equality, although it sometimes did, but it is better understood as a form of reciprocity, in which the lines between "men's" and "women's" work were blurred by the demands of family agriculture.

When newly enlisted men left their homes for training camps or for the front, they upset the fundamental unit of social organization in the countryside - the family. Men and women were concerned about how the family would survive without a man at home. Productive activity and socialization began at home, with each member of the family playing a different role, depending on age, gender, and position within the family hierarchy. ${ }^{5}$ Some of the most extensive discussions of farm affairs that women and men exchanged in their correspondence occurred during the period shortly after the men left home and things were newly unsettled. Such exchanges demonstrate varying degrees of cooperation between men and women and show the importance that the recently departed men and their wives attached to kin and community on the home front.

WHEN THE CIVIL WAR BEGAN, Iowa was an overwhelmingly rural place, even as its urban areas experienced striking growth in the 1850s. In 1860 approximately 62 percent of Iowa's workforce of 188,011 consisted of farmers or farm laborers. Since attaining statehood in 1846, Iowa had emerged as a sig-

5. For an examination of these family roles, see John Mack Faragher, Sugar Creek: Life on the Illinois Prairie (New Haven, CT, 1986); and Susan Sessions Rugh, Our Common Country: Family Farming, Community, and Culture in the Nineteenth-Century Midwest (Bloomington and Indianapolis, 2001), 20-21. 
nificant force in America's agricultural production. The states of the Old Northwest and their neighbors to the west, Iowa and Minnesota, were part of the new wheat belt of the 1850s and were becoming the nation's leading livestock producers thanks to ample corn crops that resulted from exceptionally fertile soil, adequate rainfall, and optimal day lengths and growing season. In 1860 Iowa ranked seventh in the nation in corn production and eighth in wheat production. ${ }^{6}$

The war brought tremendous changes for all Iowans, but those in rural areas experienced the war in distinctive ways. A farm was simultaneously an economic enterprise and a family residence. Men and women cooperated as husbands and wives to raise children, crops, and livestock with human and animal power. Almost all farm families relied on the labor of children and others, including adults who worked as long-term hired men or girls and occasional or itinerant laborers who were often the sons and daughters of neighboring farmers or even townspeople.

The war and the recruitment of thousands of mostly young men created a labor shortage in Iowa. In 1861 the first 14 of a total of 48 infantry regiments mustered, along with 4 regiments of cavalry and 3 artillery batteries. The next year marked a significant increase, with 25 infantry regiments and one cavalry regiment mustered for service along with the Northern Border Brigade recruited to defend Iowa's frontier from a perceived threat from the Sioux, who attacked Indian agents and settlers in Minnesota in 1862. The next year only one regiment of infantry formed, the First Colored Regiment of Iowa, later renamed the 60th U.S. Colored Infantry, although four regiments of cavalry and one artillery battery also entered service. In 1864 the state formed five infantry regiments for 100 days' service. Estimates of the total number of men who served in Iowa military units range from 72,000 to 76,000 , figures that include many men who served as replacements in existing regiments. ${ }^{7}$

6. U.S. Census of Population, 1860 (Washington, DC, 1864), 662, 680; Ross, Iowa Agriculture, 56; U.S. Census of Agriculture, 1860 (Washington, DC, 1864), 185.

7. Marshall McKusick, The Iowa Northern Border Brigade (Iowa City, 1975); Leland L. Sage, A History of Iowa (Ames, 1974), 153-54. Muster dates for Iowa regiments can be found in S. H. M. Byers, Iowa in War Times (Des Moines, 1888). 
The nature of military recruitment and organization meant that the labor shortage compounded with each passing year. With the exception of the First Iowa Infantry, which was a 90day regiment, men who enlisted in 1861 served three years or until discharged, killed, or captured. A portion of the men in those 1861 regiments reenlisted in 1864, earning the designation "Veteran Volunteer"; they continued to serve until the summer of 1865. Most of the regiments formed in 1862 served until July or August 1865 and therefore missed most of that year's growing season; the 1863 and 1864 enlistees were absent until midsummer 1865 . More than 13,000 Iowans died in military service and another 8,500 men were wounded. The farm labor shortage that was significant in 1862 and 1863 became acute in 1864 and 1865 as a growing percentage of Iowa's men was in the military or killed, disabled, or captured because of their service. ${ }^{8}$

Letters from the home front indicate the concern over the labor situation. When the war began, widow Emeline Guernsey of Wright County had two adult sons at home to handle most of the farming. One son, William, enlisted in 1861, which left the family shorthanded. Emeline reported to William in November 1861 that her younger son, Henry, was not able to finish the fall plowing because of frost. Guernsey and other neighbors were "nearly all disappointed about getting their plowing done," a situation that might have been mitigated had more young men been home. Conditions became more severe in 1863 after Henry enlisted. In a letter to William written during the small grain harvest of that summer, Emeline observed that it was difficult to get men to bind the crop after it was cut by men with mechanical reapers. "Mrs. Mark Loring was in this week," she stated, "and she said Mark was going to have a machine cut his [grain] down, and bind [it] himself afterwards. Others speak of having only four men when they harvest." An agent for the McCormick Company, the noted Chicago manufacturer of mechanical reapers, wrote to his employers from Oskaloosa in November 1864 and commented on the labor shortage in his area. Instead of hiring neighbors' sons, local laborers, or itinerant

8. Sage, History of Iowa, 153-54. 
workers, the Guernsey and Loring families made do with less by doing for themselves. ${ }^{9}$

Even after the war ended in the spring of 1865 it was a struggle to get hired help since most regiments did not muster out until mid-summer 1865 and some did so late that fall and into 1866. In the summer of 1865 John Sharp urged his wife to have some hay made in preparation for his return. Helen Sharp replied that "to get a man to do anything is out of the question." It might have been possible to purchase hay and corn, but to get hired help was nearly impossible. Not long after that exchange, John reiterated his desire to have as much as 15 tons of hay made, and Helen stated that she would "see what I can do," a vague but honest appraisal of a difficult situation. ${ }^{10}$

WHEN MARY LIVERMORE traveled throughout the Midwest as part of her service with the U.S. Sanitary Commission, she observed, from her vantage point in rail cars and carriages, that women were busy in the fields, planting, cultivating, and harvesting to a much greater extent than they had before the war. According to a hard-working farm woman she spoke with in either Wisconsin or Iowa during the summer of 1863, "the men have all gone to the war, so that my man can't hire any help at any price, and I told my girls that we must turn out and give him a lift in the harvesting," which they willingly did. ${ }^{11}$

Livermore's account is instructive, but what follows in her narrative has escaped the attention of most historians. One of the young women Livermore met in that harvest field was a daughter-in-law whose husband was in the army. The young woman's three-year-old son was in the field that day, "tumbling among the sheaves, and getting into mischief every five minutes," according to Livermore. The young wife considered herself "as good a binder as a man, and could keep up with the best of "em," but her primary attention was on her son, not the

9. Emeline Guernsey to William Guernsey, 11/26/1861, 7/31/1863, Emeline D. Guernsey Collection, Huntington Library, San Marino, CA.

10. George Mills, ed., “The Sharp Family Civil War Letters," Annals of Iowa 34 (1959), 527, 531.

11. Mary A. Livermore, My Story of the War (1887; reprint, Williamstown, MA, 1978), 145-49. 


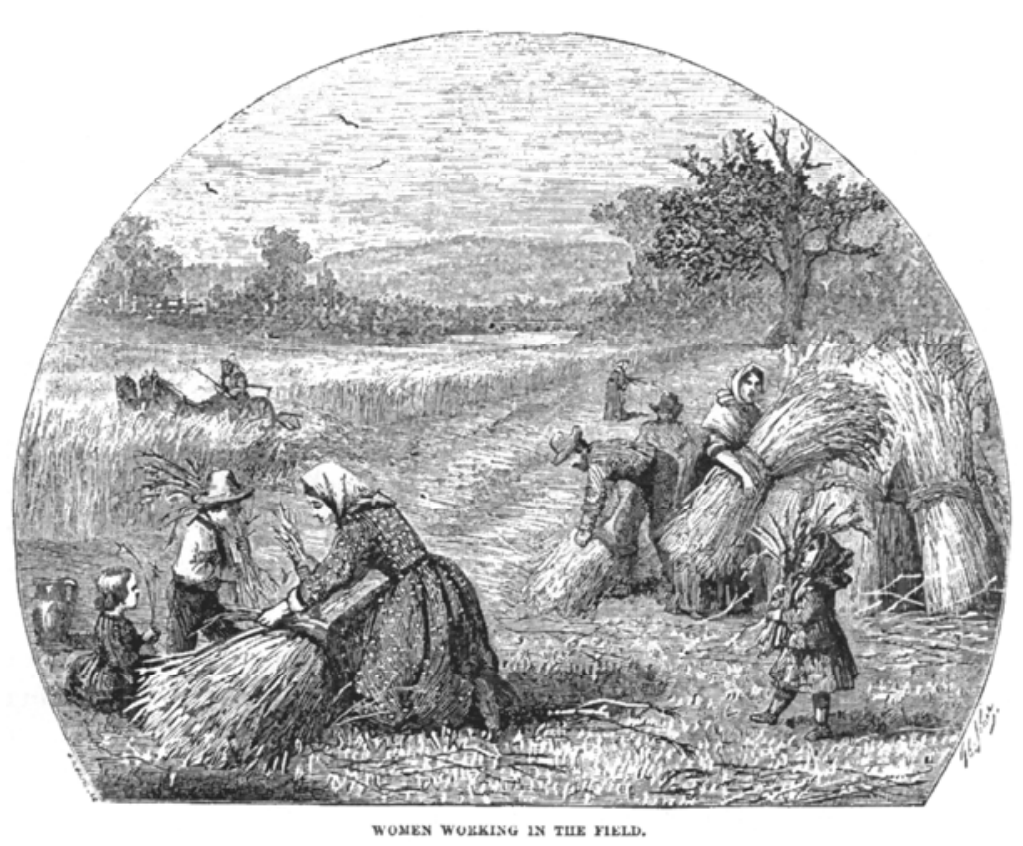

Young children work alongside their mothers in this Thomas Nast sketch, captioned "Women Working in the Fields," from F. B. Goodrich, The Tribute Book (New York, 1865), 461.

harvest. Most of the young married women left at home were busy in similar positions: raising children, preparing food, tending gardens, cleaning, and washing. Even if soldiers' wives wanted to do field work, they would have had a difficult time balancing that with their other responsibilities.

The experiences of soldiers' wives were more complicated and often more difficult than a simple story of wives serving as proxies for their departed husbands. The complexity of the story requires attention to both parties to the marriage. Charles Ackley of the Seventh Iowa Infantry balanced his advice with the recognition that his wife was in a position to know best about farm affairs. In August 1864 he inquired about the availability of harvest labor. "I knew you could drive the reaper if it was not for the children," he explained, emphasizing the importance of the family life cycle in shaping the ways women worked at mid-century. Ackley recognized that his wife's abil- 
ity to drive horses and operate an expensive machine was not the limiting factor in determining what she did on the farm. Instead, it was her duties as a mother of young children that prevented her from conducting the harvest. ${ }^{12}$

Young and unmarried women were most likely to work in the fields. Just as the sunburned woman Mary Livermore encountered put her daughters to work, so did other mothers and fathers. A farmer named Joseph Miller was proud enough of his daughter's abilities as a binder of sheaves that he was willing to wager on her. In a notice in the North Iowa Times, Miller offered a ten-dollar bet that his daughter Sarah Jane "can beat any one binding wheat who will enter the field with her as a contestant." By way of qualifications, the writer stated that "she weighs 205 pounds, and carries no extra flesh." Machinery manufacturers occasionally emphasized the ease of handling their products by advertising those machines with an illustration of a young woman driving the team and operating the machine. Tellingly, the woman depicted in one 1865 advertisement claimed, "My brother has gone to the war," not her husband. A much more likely scenario than the advertiser's vision would have been a young woman following a mechanical reaper or men with cradle scythes, gathering the stalks of cut grain and tying sheaves, as Sarah Jane Miller did. ${ }^{13}$

Many soldiers' wives did not work in the fields because at some point during the war they moved in with their parents or in-laws, where they were subsumed under the hierarchy of existing families. For women who returned to parental homes, field work was already taken care of by older men and sons who were too young to enlist. After Mathilda Peterson held an auction at her farm, she moved to Fairfield, Iowa. Cyrus Wyatt urged his wife to stay with the "Wyatt tribe" until she could "lay up enough" from her county allotment to return to Iowa, while William James of the Third Iowa Cavalry told his wife, "I am happy to hear of your staying at fathers if you can get along

12. Charles T. Ackley to Elizabeth Ackley, undated letter (probably 8/9/1864), Charles T. Ackley Collection, Special Collections, University of Iowa Libraries, Iowa City.

13. Iowa State Register, 8/16/1865. For examples of such advertisements, see Prairie Farmer, 5/27/1865 and 6/10/1865. 


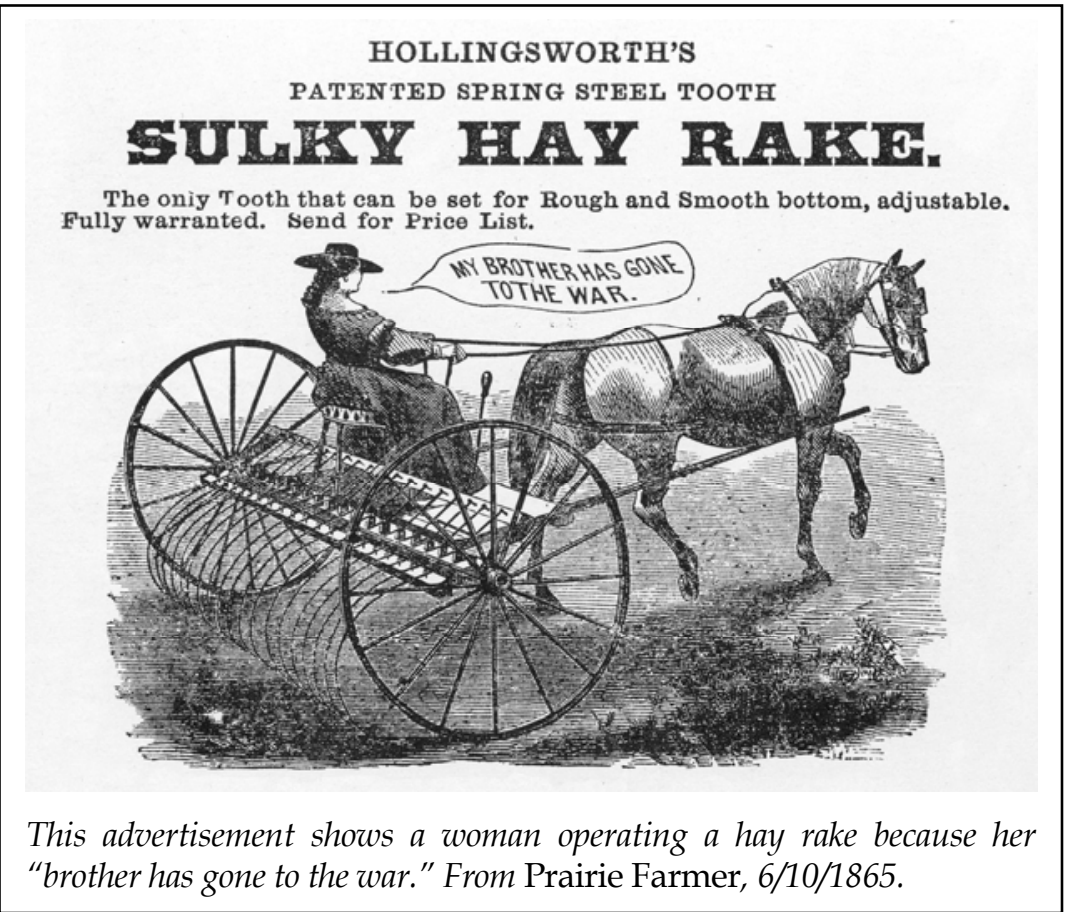

on good terms." William Sudduth composed a letter to his wife, Martha, about life at home that indicates the division of labor that he anticipated at his in-laws' farm. "Well, My Dear," he began, "How are you all getting along in Old Monona? I suppose your $\mathrm{Pa}$ has commenced planting corn, got his wheat and oats in, early potatoes + sorghum planted, wound up his sugar camp and felt business and settled himself once more to steady farming while you and Ruth and Nett are gardening, cooking, washing, milking \&tc." Part of the sustaining power of this idyllic domestic image came from the knowledge that Martha was in the care of kin. As far as William knew, his wife was not exposed to field work. She enjoyed the protection of loved ones, performed what people considered typical women's tasks, such as cooking and washing, and also attended to livestock chores, such as milking, much as she would have if William's chair at their home been occupied rather than vacant. ${ }^{14}$

14. Earl D. Check and Emeroy Johnson, eds., "Civil War Letters to New Sweden, Iowa," Swedish-American Historical Quarterly 36 (1982), 13; Cyrus Wyatt to 
The importance of kinship networks is underscored by the large number of soldiers' wives who moved in with relatives. Of the 29 farm women represented in this study, at least 17 left the farm for residences elsewhere in Iowa or other states, including Indiana, Kansas, and Pennsylvania. ${ }^{15}$ Both husbands and wives recognized that women faced tremendous difficulties in living apart from their husbands. Thomas Ball of Story County confessed to his wife Serilda that "to move out on your place to stay this winter is a dark picture to me." Ball preferred that she remain with his brother, James. "I understand James and his plan like a Book," he explained, "and that is he wants you to stay with him and I am not afraid to trust him with the whole affairs of my interest at home." 16

When Robert Stitt enlisted in the summer of 1861, his wife, Hannah, and daughter, Hilde, moved to Kansas to live with his brother. Like so many other husbands, Robert rented out the farm and arranged to have a trusted friend care for the livestock. He was, however, ambivalent about his wife's status as a dependent in his brother's home. For her part, Hannah wanted to move back home to rural Winterset. She was unhappy in Kansas and wanted to "go to keeping house a gain," although she assured her husband that she was getting along with his people and that there was plenty to eat. Robert confessed that he did not know what to advise her about living at home again, but was willing to accommodate her wishes so that she would be content. Hannah allowed that she could continue the arrangement with a friend to conduct the livestock "trading" and, underscoring the importance of kin, suggested that Robert's sister could move to Iowa with her as a help. ${ }^{17}$

Catherine Wyatt, 11/9/1863, Cyrus Wyatt Letters, SHSI, Des Moines; William F. James to Marcia James, October 1864, William Francis James Letters, SHSI, Des Moines; William J. Sudduth to Martha Sudduth, 5/4/1863, William James Sudduth Collection, SHSI, Des Moines.

15. Six women appeared to remain on the farm for the duration of the war; it was impossible to determine the location of another six women.

16. David B. Danbom, “'Dear Companion': Civil War Letters of a Story County Farmer," Annals of Iowa 47 (1984), 539.

17. Hannah Stitt to Robert Stitt, 7/4/1864; Robert Stitt to Hannah Stitt, 7/2/ 1863; James G. Craine to Robert Stitt, 8/21/1863, all in Robert A. Stitt Collection, SHSI, Des Moines. It is unknown if Hannah was able to begin housekeep- 
Kin networks also shaped the ways women who remained on the farm experienced the war. The first priority for husbands and wives was how to provide for the family. Husbands often approached a trusted friend, neighbor, or relative to manage the farm in their absence. Elisha Leaming was relieved that "father" had found a good renter for their farm. Jasper and Mary Rice parted in August 1862, when Jasper responded to President Lincoln's call for 300,000 men. Rice told his wife that a Mr. Boyce would attend to the farm and see to her needs. Adam Schaefer of the 17th Iowa corresponded with his Jefferson County neighbor William Whisler about managing the farm on his wife's behalf after he departed in spring 1862. In March of the following year, Schaefer expressed his wish to Whisler that he would "see to renting my farm to the best advantage, and see that my family are not suffering." C. J. Peterson of the settlement at New Sweden urged his wife to ask her brother Anders for assistance. William Donnan of Buchanan County advised his brother to take care of taxes on his family farm. Husbands and wives understood that there were many decisions to make and tasks to perform, and that it was an added burden for women to bear alone. Furthermore, most land was in the husband's name, reinforcing traditional male roles as the head of the household. Securing help, while in part an exercise of patriarchal authority, was also a caring gesture. ${ }^{18}$

It made sense to most families with absent husbands for kin to help run the farm and for wives and children to move in with parents or in-laws, but for a male who was not a family member to move in with a wife whose husband was away challenged conventional morality. The rarity of such an event is the exception that proves the rule of reliance on kin for live-in support. John and Ann Wright, farmers from the Pacific Junction area

ing again in Iowa, since the correspondence between her and Robert ended in August 1863 after a letter from one of the Kansas relatives to Robert informed him about his wife's itinerary for the trip home to Iowa.

18. Elisha Leaming to Louisa Leaming, 4/1/1865, Elisha Leaming Collection, SHSI, Des Moines; Jasper Hazen Rice to Mary Rice, 9/12/1862, Special Collections, University of Iowa Libraries; Adam Schaefer to William Whisler, 3/6/ 1863, Whisler-Reppert Family Papers, SHSI, Iowa City; “Civil War Letters to New Sweden," 8-9, 12-14; William Donnan to Mary Donnan, 11/20/1862, William G. Donnan Collection, SHSI, Des Moines. 
faced this kind of scrutiny late in the war. Wright enlisted in the summer of 1863 and immediately counseled Ann that someone known as Ap, possibly a relative, would provide advice and assistance. In the summer of 1864 , however, a man named Peter moved in with Ann to take care of livestock and cut wood. Ann stated her concern that "staying alone with Peter" would be a source of gossip among the neighbors; however, John assured her that she was "doing purfectly right." "For my part," John explained, "it would look more suspicious to see a woman liveing alone than to have a man about the house," implying that a single woman would be suspected of being a prostitute. John believed that Peter was a good man and that Ann had nothing to fear as long as she would "carry yourself strait which I am satisfied you will do. . . . Let the scalawags of the country talk." This kind of living arrangement was a violation of social norms of the time and was unique among separated couples. The pressure of gossiping neighbors was an acknowledged fact. A brother or brother-in-law who moved in would have been unlikely to raise questions about the wife's morality. The Wrights breached the unspoken rule of moving off the farm to live with kin or inviting a brother or brother-in-law to move in to conduct farm work and preserve the household during soldiers' absences. ${ }^{19}$

In many cases relatives took over the day-to-day work in addition to the management. When Samuel Glasgow of Page County enlisted in 1862, he asked his father to harvest the corn crop that fall and to sell one of their three horses. Agnes and Amasa Allen counted on Amasa's father and a man named Charles, who appears to have been a brother, to run the farm. Agnes wrote to her husband shortly after he left home in the summer of 1862, hoping that his father would see to harvesting and processing the sorghum crop. Later that fall, Amasa's father marketed their hogs and promised to send Agnes some of the proceeds from the sale and to keep some money for the purchase of hay to winter the rest of the livestock. ${ }^{20}$

19. John D. Wright to Ann Wright, 8/18-19/1864, John D. Wright Collection, SHSI, Iowa City.

20. Samuel Glasgow to Emma Glasgow, 12/22/1862, Samuel H. Glasgow Collection, SHSI, Des Moines; Agnes Allen to Amasa Allen, undated letter (proba- 
During the long separation of Rachel and William Coffin, William relied on a man named Anderson to manage affairs at home. William regularly reported to his wife whether he had heard from Anderson and provided her with details about farm affairs. In the summer of 1863, William told Rachel about what was happening back home based on correspondence from a neighbor, who reported that the grain crop on the Coffin farm was excellent, with oats "the heaviest he ever raked off of the platform [of a reaper]." After the harvest, William, not Rachel, arranged to have the wheat ground and hauled. ${ }^{21}$

SO MANY WOMEN left the farm or relied on the assistance of male kin and neighbors because the challenges of staying on the farm without a husband were immense. Husbands and wives plotted and planned about fuel procurement, payment and collection of debts, disposal of unneeded chattels, management of farm tenants, care of livestock, and numerous other tasks. These were the subjects of countless exchanges between spouses.

Some couples made careful arrangements to provide security for the family before the husband left. As soon as Samuel Rogers joined the 30th Iowa Infantry as assistant surgeon, he and his wife rented out their farm and sold most of their cattle, horses, chickens, and turkeys, retaining one cow and some poultry to meet family needs. Machinery and wagons, assets that required less care, remained on the farm until the family returned. ${ }^{22}$

Not all families were able to put all their affairs in order. Some husbands recognized early in their military service that women were the managers whose opinions mattered since they were the ones who had to make decisions and implement plans. Just two weeks after John Sharp enlisted in November 1861, he wrote to his wife, Helen, and advised her to have the deed, presumably to the farm near Fort Des Moines, made out in her name. In her reply, Helen chided her husband for not recording

bly September 1862), and Amasa Allen to Agnes Allen, 11/25/1862, Amasa Orlando Allen Collection, SHSI, Des Moines.

21. John B. and Donna L. Chapman, eds., Love Letters from the Civil War (Ames, 2000), 53, 55.

22. M. A. Rogers, “An Iowa Woman in War Time," Annals of Iowa 35 (1961), 541. 
the deed before he left. "Now if you want me to have a deed," she wrote, "write to the one that has the deeds to make and then maybe they will do it." Helen in effect redelegated a task to her husband that he had hoped she would do. ${ }^{23}$

Women often acted on their own in making decisions about the farm. Helen Sharp is one of the best examples of an assertive farm woman, although she seldom appeared to be happy about it. She often asked her husband for advice, but in many cases she relied on her own counsel either because she wanted to do so or felt she had no choice. In April 1862 she reported to her husband all the work she had done to move the family to a new farm that spring. She was unable to move all of her flock of chickens because of a lack of cages, so she sold the balance to a neighbor and used the proceeds to purchase cornmeal and molasses for her family and hay for her cow. She made these decisions and presented them to her husband after the fact, with no mention of any guidance by outsiders. ${ }^{24}$

Financial decisions were among the most common management issues women confronted. Less than a month after Jasper Rice departed, he urged Mary to use her discretion to dispose of things on the farm that would not be needed until he returned. That next spring she did so with some success. In a letter dated April 1863 Jasper conceded, "I must give you credit for your good management. I think when I get home I will let you do the financiering." He reckoned that she was "making some prety good trades" for farm implements. Similarly, C. J. Peterson praised his wife Matilda's success in liquidating assets on their farm. "I see that you have had an auction," he wrote, and assured her that she had made a good decision to do so. Two weeks later, he noted that the family had earned 72 dollars from the sale, which, among the many items sold, included 80 shocks of corn in the field, a move that not only generated income but also saved a great deal of labor or expense for Matilda or some other family member who would have had to haul it to a barn or livestock pen for feeding. ${ }^{25}$

23. “Sharp Family Civil War Letters," 483, 486.

24. Ibid., 494.

25. Jasper Rice to Mary Rice, 9/12/1862, 4/13/1863, Special Collections, University of Iowa Libraries; "Civil War Letters to New Sweden," 12-13. 
Collecting and paying debts often fell to women, although men regularly provided reminders and advice. Amanda Barnes's husband, William, urged her to "sell pork enough to pay George Shurman and our taxes if you can." William Donnan of rural Independence reminded his wife, Mary, to notify him "if Fs pay us what little they owe us before they go away," which served as an indirect reminder for her to collect the debt. Little more than a week later he wrote that the paymaster had arrived and he would be sending money home, which meant that Mary needed to visit creditors to reconcile accounts. "I want that Butler matter paid," William directed. "Then [pay] our taxes and Jim then if you have any more than you want for your own use apply it to that 400 still due for that land." Joseph Coffman urged his wife, Maggie, to sell 40 to 50 bushels of wheat in December 1864 to "try to get money enough to pay of[f] the Reaper [note]." Admonitions to pay or collect debts were most frequent toward the beginning of the soldier's enlistment when the family's future seemed most unsure to the newly separated. As husbands' directives about debts suggest, women and men collaborated to manage the farm. It is unclear whether the reminders and advice were always welcome, but absent husbands continued to advise wives and exercise a limited degree of control over the financial management of the farm. ${ }^{26}$

In addition to providing guidance on farm finances, men offered practical suggestions about livestock husbandry and crops. Not surprisingly, women often sought counsel on such farm issues, since men were generally responsible for that knowledge. Helen Sharp asked her husband's opinion about selling a cow that was a good milk producer but continued to lactate and therefore did not come into estrus, or heat. "Had I better sell her to a drover if I can?" she inquired. "I do not think she will pay to keep[,] though I think she is a first best young cow." In the fall of 1862, Harriet Thompson of Linn County informed her husband that a man wanted to purchase the family cow for 13 dollars. "I wish you would tell me what to do," she pleaded.

26. William Barnes to Amanda Barnes, 8/29/1864, William R. Barnes Collection, SHSI, Des Moines; William Donnan to Mary Donnan, 4/3/1863, 4/16/ 1863, Donnan Collection; Joseph Coffman to Maggie Coffman, 12/13/1864, Joseph A. Coffman Collection, SHSI, Des Moines. 
Thompson had just returned to Iowa from Pennsylvania, and was possibly unfamiliar with the cow's current condition and value. ${ }^{27}$

Husbands regularly responded to pleas like these throughout their enlistments, offering financial advice and practical guidance about maintaining the farm. Emma and Samuel Glasgow often discussed the farm in their letters, and Samuel retained a high degree of control. He continued to make financial arrangements long after his departure, informing Emma of his dealings mostly after the fact. In early 1863 he told his wife that he owed 24 dollars to a man in his company for a wagon, which he planned to repay as soon as the paymaster arrived to pay off the regiment. Charles Ackley of rural Marble Rock pressed his wife in the spring of 1865 to hire a breaking outfit to plow up more prairie acres that spring in preparation for an expansion of operations. As the summer peaked in August 1865, Silas Shearer provided his wife with specific instructions about tasks to be accomplished before his return home, including directions to hire someone to cut hay and stack it near the stable for feeding calves that winter, since he would not be home in time to make hay. Similarly, C. J. Peterson offered extensive instructions about plowing and planting for his wife to relay to her brother and a man named Lind. ${ }^{28}$

Women sometimes increased the size of their families' herds or added new livestock. In an exceptional case, Sarah Lacey acquired nine milk cows during her husband's absence and sold large quantities of butter that provided income for her family. More often, women made modest changes in family herds. Like Ann Larimer, introduced at the beginning of this article, Elizabeth Jane Shearer purchased two sheep in 1864. Her husband, Silas, then on campaign in Arkansas, applauded the move. "If you can get two or three more I want you to do it," he urged. "They will not be very much bother to you until I get home if I am so lucky as to get home." Even as he encouraged her in the

27. "Sharp Family Civil War Letters," 499; Glenda Riley, ed., "Civil War Wife: The Letters of Harriet Jane Thompson," Annals of Iowa 44 (1978), 311.

28. Samuel Glasgow to Emma Glasgow, 2/5/1863, Glasgow Collection; Charles Ackley to "Dear Wife," 5/12/1865, 5/26/1865, Ackley Collection; "Civil War Letters to New Sweden," 14. 
sheep business, Silas assured his wife that he understood that it was likely difficult to obtain more sheep, given the premium on wool. Maria Kimberly innovated and purchased geese in 1864 . Although her letters are not extant, her husband, Uriah, wrote that he was "quite well pleased with your experiment with geese." Uriah commented that he would not have wanted to tend geese because they were "a dirty set of things," but she must have done well when she sold them, based on his positive response to the experiment. ${ }^{29}$

In spite of some successes with livestock husbandry, women often sold off livestock to reduce the management task they faced. Farm animals were portable assets, but they also required a lot of work. Sometimes the work was defensive, such as building fences around the house in the fall to keep animals away from the home in the winter. Chores required exposure in severe weather, which was a burden for women with small children. A reasonable solution was to cull the herd, often keeping only a milk cow, some poultry, and a hog or two to meet family needs. Elisha Leaming urged his wife, Louisa, to have her father "sell off all the [live]Stalk that you can['t] git along with." C. J. Peterson was so pleased that his wife had sold the family's steers that he subsequently requested that she ask her brother to board their horses to minimize her extra work. In the summer of 1865 John Larimer counseled Ann to sell the cattle if she had a chance. Although she was unsure why he wanted her to do so, Ann responded that she would if she could "sell them for a good price . . \& \& if not, why, I will keep them until fall \& see if you are not home to attend to them." 30

One of the most vexing wartime issues for couples was how to provide firewood for women who lived without an adult male in the household. Such women relied on others to meet that basic need. It is impossible to know the extent to which the fire-

29. E. May Lacey Crowder, "Pioneer Life in Palo Alto County," Iowa Journal of History and Politics 46 (1948), 160; Harold D. Brinkman, ed., Dear Companion: The Civil War Letters of Silas I. Shearer (Ames, 1995), 111; Uriah M. Kimberly to Maria P. Kimberly, 6/10/1864, Uriah Kimberly Collection, SHSI, Des Moines.

30. Elisha Leaming to Louisa Leaming, 4/1/1865, Leaming Collection; "Civil War Letters to New Sweden," 8-9; Ann Larimer to John Larimer, 7/13/1865, Larimer Collection. 
wood supply was a source of marital tension when husbands and wives lived together, but it is apparent that both parties were dissatisfied with the way the men on the home front did the job. Sometimes the comments were comparatively benign, such as Uriah Kimberly's suggestion that his wife invite neighbors to "make a wood hauling" and get it chopped on her behalf. Most couples were disgusted or angry with those who were appointed or agreed to assist. Helen Sharp complained to her husband on several occasions that she had "something of a hard time about wood," although on at least two occasions a neighbor came to provide her with some. In early June 1864 Joseph Coffman wrote to his wife, "I see you are somewhat neglected by the so called friend in not keeping you in plenty of wood." The renter who was supposed to operate the farm had left before completing his term, forcing Coffman to find another solution. He advised that it was not safe for Maggie to stay on the farm alone "and be without wood half the time." In another June letter, he expressed the hope that "you will not have to do all the chores, and chop your own wood." 31

Managing tenants was a time-consuming task that usually fell to men. The Coffins' relations with their neighbor Anderson were cordial, at least as far as can be discerned from the letters between Rachel and William. Amasa and Agnes Allen also appear to have successfully rented out their farm with absentee management by Amasa. Allen told his wife in early 1863 that if his brother Charles had not yet sold the farm, "I can rent the land to the Bigalow boys and Father next season." He apparently did, as that March Amasa wrote to his wife that his father and the neighbors "will sow our land to wheat if they can get the seed[,] if not they will sow it to Oats so it will not lay waist." 32

Landlord-tenant relations were often strained, and men and women sometimes found themselves powerless due to their separation. Maria Kimberly reported to her husband, Uriah, that a local man who had agreed to rent a portion of their farm had backed out. "I was sorry to hear how Frank Longwell had served

31. Uriah Kimberly to Maria Kimberly, 8/13/1864, Kimberly Collection; “Sharp Family Letters," 487, 495, 497, 513; Joseph Coffman to Maggie Coffman, 6/3/ 1864, 6/13/1864, Coffman Collection.

32. Amasa Allen to Agnes Allen, 1/26/1863, 3/12/1863, Allen Collection. 
you," he noted. Uriah complained that Longwell had "rented 20 acres of that land fare and square and then back out when it was to[o] late to let it out to any body else." Later in that letter he told his wife to extend thanks to a woman named Vina who served as a proxy by exchanging strong words with Longwell. "I thank her very much," he said, "for takeing my place whilst I am in the army and I don't care how she talked to Frank for I think that he has treated you very mean indeed." Uriah could only dream about settling scores with the person who wronged his family. ${ }^{33}$

Numerous other problems dogged farm families - problems that were not unique to wartime conditions, but, like the Kimberlys' dispute with Frank Longwell, were complicated by the absence of men folk. When Emma Glasgow informed her husband, Samuel, that some hogs had ventured into their cornfield and damaged the crop, he lamented that he was not there to help. "I ought to be there with the old shot Gun," he wrote. Samuel inquired if his wife could find out who owned the hogs "and tell them for me that any man that will let his hogs distroy a soldier's corn is worse than a Secesh and no man atal." Glasgow's sense of manhood was threatened when he could not be present to solve a problem that would have been easier had he been at home. Maria Kimberly struggled with a new and faulty pump, but Uriah was the one who had purchased it and possessed knowledge of the terms of sale. In a long and rambling section of a letter, Uriah insisted that the agent could not make her pay for the pump if it did not work properly. His sense of outrage was matched by a sense of powerlessness and a recognition that his wife was doing the best she could. He concluded that if he was at home, they "would talk some any how but I don't know as it would do any good any how." 34

For most Iowa farm couples, farming during the war was a true partnership, regardless of whether couples used affectionate prose and pet names or businesslike language. William Vermillion, a physician and farmer, often inquired of his wife, Mary, about the farm and tenants. In May 1863 he wrote, "I

33. Uriah Kimberly to Maria Kimberly, 6/14/1864, Kimberly Collection.

34. Samuel Glasgow to Emma Glasgow, 9/14/1862, Glasgow Collection; Uriah Kimberly to Maria Kimberly, 8/30/1864, Kimberly Collection. 
want you to write me everything. ... All about how Teater [the tenant] is getting along. If you think he is doing all right tell me so Dollie, and if he is doing wrong tell me." William's letters indicate that he assumed that Mary was knowledgeable about the farm but did not expect that she would take an active role in managing it. The few times he asked her to engage in farm affairs were in regards to livestock. In June 1863 he urged her to sell a heifer, oxen, mules, and corn "if you think best." He followed up with an explanation that the corn was likely to go to waste where it was. Later that summer he urged her to "sell cattle to the best advantage as soon as you can," and he wanted greenbacks rather than promissory notes. This is a typical pattern in many couples' correspondence-respectfully offered advice qualified by a statement of recognition of the limitations of advice from afar. ${ }^{35}$

Even husbands who gave direct orders recognized that their authority had limits and that their wives would be the ones living with the immediate consequences of any management decisions. Most soldiers, like Vermillion, almost always extended the benefit of the doubt to their wives and understood that wives were more knowledgeable about current farm affairs than they could be from afar. In a letter in February 1865 Silas Shearer wrote, "Well Jane I wrote to you to traid that place off [but] I am not very particular whether you do it or not. It is a nice little place and it will make us a good home. Make a good traid if you traid it, if you can't keep it." If absent husbands did not have a high level of confidence in their wives' abilities to preserve the farm when they enlisted, they must have gained it during their service. ${ }^{36}$

COUPLES SHARED management duties while separated, but they still had to contend with the absence of the husband as a farm worker who milked the cows, mended fences, plowed the fields, and planted, cultivated, and harvested the crops. The absent husband rendered judgment and provided advice, but the

35. Donald C. Elder III, ed., Love amid the Turmoil: The Civil War Letters of William and Mary Vermillion (Iowa City, 2003), 90, 125, 180.

36. Dear Companion, 127. 
chair remained vacant; someone needed to provide the skilled and unskilled labor to keep the family together. Mary Vermillion protested to her husband that "when I can do nothing else, I am willing to work to raise corn, to pay taxes, to help sustain the government, and carry on the war." Mary was willing to take hoe in hand, but she was not driven to field work. She resided in town and later with her parents in Indiana. Meanwhile, renters carried on the work at the farm they called Woodside. ${ }^{37}$

Some women did take on a heavy load of the physical labor required to operate a farm. Under the headline, "VALUABLE WOMAN," a newspaper report from Guthrie County in the fall of 1865 noted an instance of a woman who tended a nine-acre cornfield that yielded 550 bushels. The editor of the Des Moines paper that ran the piece commented that women were not only responsible for operating farms but also for performing the physical labor. Helen Sharp assisted in stripping sorghum cane in preparation for making molasses in 1862, but her notation of that kind of field work was rare among the correspondence of soldiers and wives. ${ }^{38}$

For many native-born citizens there was a stigma associated with women working in the fields. Supposedly, only immigrant women, perceived by the native-born as ignorant, muscular, and dirty, stooped to such work, a view shared by Mary Livermore until her conversations in the fields of the Midwest in 1863 changed her mind. Many foreign-born women who were accustomed to field work did it without complaint. Some immigrants who settled in Iowa actually looked down on American women who refused to work in the field. According to a Dutch immigrant, American farm women were more interested in new dresses and horseback riding than in farm production. But for the majority population, only the most desperate circumstances could compel a woman to take up a hoe or plow. ${ }^{39}$

37. Love amid the Turmoil, 85.

38. Iowa State Register, 11/26/1865; "Sharp Family Letters," 513.

39. Jon Gjerde, The Minds of the West: Ethnocultural Evolution in the Rural Middle West, 1830-1917 (Chapel Hill, NC, 1997), 151, 171-73. For a description of how one immigrant described native-born women, see Robert P. Swierenga, "A Dutch Immigrant's View of Frontier Iowa," in Dorothy Schwieder, ed., Patterns and Perspectives in Iowa History (Ames, 1973), 58-59. 
The editor of a Des Moines newspaper combined nativist sentiment with Democratic suspicions about abolition as a war aim when he printed a notice from a Wisconsin newspaper describing the farm labor shortage. The notice highlighted the role of "German, Norwegian, and Bohemian servant girls" in conducting the summer grain harvest. It was not necessary, he stated, to go to Wisconsin to observe "female labor in the corn fields. Such instances can be found all over this state." In his view, that development was the lamentable product of a war for abolition, and he blamed those who had precipitated war and would continue it until the South was subjugated "in order that the Negro may be freed." A writer for the Dubuque Herald disagreed, contending that women would benefit from abandoning "corsets, belts, and cosmetics" and, by working in the fields, "strengthen their frames ... grow robust instead of slender, rosy instead of pallid, brown rather than delicate." Most Iowans, regardless of party affiliation, hoped to avoid being driven to such extremes as women with suntans, strong backs, and muscular arms. They were spared the discomfort of witnessing many soldiers' wives doing men's work, although many young women were hard at work in the fields. ${ }^{40}$

Wartime correspondence indicates that wives who went to the fields to plow, plant, cultivate, or harvest were the exception, not the rule. Ann Larimer's comment to her husband about the sheep is suggestive of the physical work women did in addition to traditional gendered labor such as gardening, food preparation and preservation, cleaning, and child care. Unlike field crops, the animals, or "stock," as husbands and wives stated, were property that retained value or even appreciated in value from year to year, and therefore represented a larger share of family resources than any single field crop or combination of crops. William Barnes offered only the most general advice to his wife about livestock, urging her to tend to the animals "as well as you can." Larimer and many other women often took over livestock chores, even if they rented their farms to others. ${ }^{41}$

40. Des Moines Daily Statesman, 8/13/1864; Dubuque Herald, cited in Dorothy Schwieder, Iowa: The Middle Land (Ames, 1996), 80.

41. William R. Barnes to Amanda M. Barnes, 11/6/1863, Barnes Collection. Economic historians Lee A. Craig and Thomas Weiss, "Agricultural Productivity 
Women who remained on farms sometimes performed livestock chores and confronted extreme weather, which was a source of complaint by their husbands. In the fall of 1862 Thomas Lewis inquired what his wife, Lucinda, had done with their livestock. His concern was less about financial security and more about Lucinda's health. He did not want her to "expose" herself to severe weather by doing demanding livestock chores. He cautioned her that "you had Better Sell it [livestock] rather than weary youre Self to take care of it." Jasper Rice told his wife that he did not want her to do too much work outdoors. Similarly, Charles Ackley was concerned about his wife's health. She was also a schoolteacher, and he urged her to obtain a teaching position and even to seek appointment as postmaster to avoid the exposure of feeding and watering animals in all kinds of weather. An observer from Floyd County captured the prevailing mood of Iowa's men folk when he stated that women should be encouraged to do light work outdoors "that tends without degradations to improve women's physical condition, to make her fairer, and less dependent on the man." Heavy work, he advised, was to be avoided. ${ }^{42}$

THE MOST IMPORTANT ROLE women assumed during the separation from their husbands was as farm managers. Historians dispute the extent to which women were involved in farm decision making before the war. During the war, however, farm women made important decisions, often in consultation with their husbands or male kin, about raising crops, tending

Growth during the Decade of the Civil War," Journal of Economic History 53 (1993), 527-48, argued that much of the productivity gain on Northern farms during the 1860s resulted less from mechanization and more from "an increase in the time and effort men, women, and children devoted to the production of marketable farm products. The fact that much of this increase came from women is of particular interest." The authors suggest that the Civil War's counterpart to Rosie the Riveter could be "Hilda the Hog Herder." At least in Iowa, productivity gains from women's work must have come from women whose husbands were not in the military.

42. Thomas J. Lewis to Lucinda J. Lewis, 10/18/1862, Thomas Jefferson Lewis Collection, SHSI, Des Moines; Jasper Rice to Mary Rice, 9/12/1863, Special Collections, University of Iowa Libraries; Charles T. Ackley to Elizabeth Ackley, 10/23/1864, Ackley Collection; Iowa State Agricultural Society Report, 1863, p. 355, cited in Gilford, "Agricultural Labor Shortage," 35. 
livestock, acquiring land, and making rental arrangements. But even as the war brought new roles and new labor for farm women who lived with vacant chairs at their tables and in their parlors, it also reinforced traditional roles and positions within family hierarchies. The majority of soldiers returned from the war to resume their work on the farm. Some, including Uriah Kimberly and Adam Schaefer, did not come home. Their wives confronted the continuing reality of dealing with farm affairs in addition to their suffering.

The Civil War was a great test for rural Iowans, just as it was for the nation. Farm women with absent husbands became managers and diplomats who negotiated relationships with kin and neighbors to provision and shelter their families and to preserve their farms. They confronted tenants, creditors, and debtors, and sometimes marketed livestock and crops. They asked kin and husbands for advice, received it, and, it appears, generally followed it. Husbands almost always recognized the limits of their counsel, however. Even when husbands provided copious advice, they reminded themselves and their wives that the women were in a position to know best. Few soldiers' wives were compelled to work in the fields, but many of them shouldered a greater share of livestock chores than they had before the war. A significant percentage, perhaps even a majority, of women with husbands in the military left their farms, taking refuge with kin for periods of varying length until their husbands returned. Surviving letters of farm couples separated by the war indicate that farm women, whether they remained on their farms or departed, were successful in doing what they and their husbands desired, providing for their families to best advantage. 